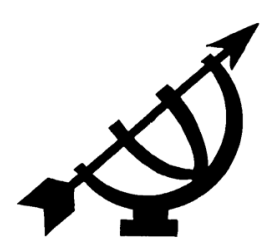

\title{
Dialogical inquiry as an instrument of the reconciliation of conflict in the hands of Christian leaders
}

\author{
C.J. Hugo
}

Department of Practical Theology

University of South Africa

PRETORIA

E-mail: hugocj@unisa.ac.za

\begin{abstract}
Dialogical inquiry as an instrument of the reconciliation of conflict in the hands of Christian leaders
\end{abstract}

The apartheid system caused deep rifts in South African society, and even following the dawn of democracy, society in South Africa continues to struggle with violence and conflict, ethnic differences, mass action and poverty. Christian leaders have an important part to play in conflict resolution. Conflict management in organisations incorporates negotiation as a means of conflict resolution. A number of approaches to conflict resolution contribute to this approach; these include forcing, avoiding, accommodating, compromising and collaborating. Christian leaders, however, favour reconciliation as a means of resolving conflict. A Christian approach to conflict resolution needs to take cognisance of the existential aspect of conflict. Examples of such approaches are those of Dreyer, who speaks of reconciliation as a dilemma for forgiveness, and Kistner, who explores the way in which the use of narratives rather than reallife stories in the Truth and Reconciliation Commission reduced the severity of trauma. The social construction of trauma in "Mamelodi" by Brigid Hess, which presents a shift from forgiveness to a journey taken along with the perpetrators, and the belief of Desmond Tutu in the healing brought about by the ubuntu philosophy, are evaluated here as being detrimental to reconciliation. Based on the examples cited, an approach to conflict resolution entailing a clear integration of the biblical approach to reconciliation and dialogical inquiry $(D I)$ is proposed as an appropriate intervention approach for Christian leaders. The 
present contribution is offered from within the discipline of Practical Theology, with a focus on Pastoral Counseling.

\section{Opsomming}

\section{Dialogiese onderhandeling as instrument vir die versoening van konflik in die hande van Christenleiers}

Suid-Afrika is 'n land waarin die samelewing diep verdeeld was as gevolg van apartheid. Met die aanbreek van die nuwe demokrasie moet die samelewing steeds probleme konfronteer soos geweld, konflik, etniese verskille, massa-aksies en armoede. Christelike leiers het 'n behoefte aan konflikhantering. Konflikhantering as deel van interpersoonlike dinamika in organisasies inkorporeer onderhandeling as 'n metode van konflikoplossing. Verskillende benaderings tot konflikoplossing dra by tot hierdie benadering: dwang, vermyding, akkommodering, kompromie en samewerking. Christelike leiers verkies egter om versoening as metode van konflikhantering te gebruik. 'n Christelike benadering tot konflik moet die eksistensiële aspek van konflik deeglik verreken. Voorbeelde van konflikhantering waarin versoening 'n rol speel, is Dreyer se siening van versoening as 'n dilemma vir vergifnis, asook Kistner wat die gebruik van narratiewe in plaas van lewensgetroue stories in die Waarheids-en-versoeningskommissie ondersoek. Dit het gelei tot die vermindering van die ernstige aard van trauma. Die sosiale konstruksie van trauma in "Mamelodi" deur Brigid Hess, wat 'n skuif weg van vergifnis na 'n lewenstog met die aanstigters van die trauma verteenwoordig en die oortuiging van Desmond Tutu dat genesing deur die ubuntu-filosofie bewerkstellig word, word hier geëvalueer as teenproduktief vir versoening. 'n Benadering wat gebaseer is op die integrasie van 'n Bybelse benadering tot versoening en die gebruik van dialoog word hier vir Christelike leiers voorgestel. Hierdie bydrae is vanuit die Praktiese Teologie, met Pastorale Berading as fokus.

\section{Reconciliation as dilemma for conflict resolution}

The focus of this article is on the role of Christian leaders in conflict resolution. Christian leadership tends to focus on forgiveness and reconciliation as a means for resolving conflict. An outstanding example of conflict resolution in South Africa is the work of the Truth and Reconciliation Commission (TRC), which, in October 1998, published a five-volume report. The TRC noted that if it was to bring about reconciliation, it had to ensure access to reparation and rehabilitation: there can be no healing and reconciliation at either an individual or community level without access to rehabilitation. The TRC had six purposes: to generate a detailed record of the extent of 
human rights violations in South Africa; to document the nature and causes of human rights violations in South Africa; to name those responsible for the violations; to provide a public forum in which the victims could express themselves; to make recommendations to prevent future abuses; and to make reparations to victims and grant amnesty to those who made full disclosure of their involvement in such violations. Archbishop Desmond Tutu has described this commission as working within the paradigm of restorative justice, in contrast to paradigms that rely on the prosecution of war criminals through special tribunals (Strang \& Braithwaite, 2001:86). The outcomes of the TRC are an example of destructive conflict management. Two approaches to conflict management were identified by Louw (1987:40). He distinguishes between destructive conflict management, which entails confrontation and manipulation, and constructive conflict resolution, which entails negotiation, compromise and reconciliation. Various authors have commented on the outcomes of the TRC, and reached the conclusion that rehabilitation was replaced by the initiative to build a new nation. Elements of deconstructive conflict resolution are evident in the TRC's approach. The Christian imperative to reconcile created a theological existential dilemma, which brings us to the importance of the need for an approach that goes beyond the imperative to build a nation but which can address the existential need for healing. This observation is confirmed by Dreyer in her discussion of the role of forgiveness in pastoral care.

Dreyer (2005) refers to Christie Neuger (2001), who explores the problematic implications for pastoral counseling for victims of violence: if forgiveness does not lead to healing, the victim is left with many unresolved feelings and cognitions. She argues that when the message of forgiveness is based on the theological (objective) solution that Christ was crucified, and that all Christians can and must forgive all perpetrators, a dilemma arises. For Neuger, this first-order change entails faith in the biblical message of forgiveness without any focus on a change in the existential dimension of the victim. Existential change includes the configuration of psychological and theological dimensions, not only a biblical conceptualisation of forgiveness. She claims that the differentiation between a rigid biblical and an existential approach is consistent with the differentiation between the objective doctrine of reconciliation and the subjective doctrine of reconciliation. This difference is explained by Smit in his exposition of the text of 2 Corinthians 5:18-21. 
Smit (1982), in his exposition of 2 Corinthians 5:18-21, explains that the objective doctrine of reconciliation is interpreted as satisfactio vicaria, meaning that the guilt of humankind is reconciled on the cross as an objective, God-given act of salvation. The subjective approach has been explored by Dorothee Sölle (Stellvertretung) and Herman Wiersenga (Verzoening als verandering), both of whom conceptualised reconciliation as verandering or transformation focused on life-changing subjective existential experience. It is this aspect or emphasis that seems to be needed in a pastoral or Christian approach to conflict resolution.

Another example of the deconstructive use of reconciliation is supplied by Kistner (2003), who discusses the linguistic differences between the use of story and narrative in testimonies before the TRC in South Africa, and identifies different notions of the concept truth as one of the skeletons. She writes:

The tropes (participants) of the TRC were centrally organized around victims and perpetrators and heroes and martyrs in the struggle. Testimony of experiences of violation was often translated into sacrifice of childhood, youth, education, well being and life itself. The hearings often ended with everyone present being asked to stand and observe a minute of silence for those who became the nation's fallen heroes. (Kistner, 2003:6.)

Kistner bases her argument on the difference between a narrative, used by the TRC for the purpose of nation building, and storytelling, which is the recounting of individually experienced historical trauma, and makes the observation that the TRC easily "slid between these two sources of trauma, reducing the two types of trauma to each other and interchangeably deriving one from the other". She concludes that the TRC's fact-finding role was in conflict with its role as a "psychologically sensitive mechanism for storytelling and healing" (Kistner, 2003:11). These two examples can be identified as examples of conflict management rather than conflict resolution.

In the light of the above-mentioned examples by leaders who adopted a Christian approach to reconciliation, the following question needs to be asked: what approach should a Christian leader adopt in order to bring about the resolution of conflict? In preparation for a suggested answer to this question, a brief exposition of the context of conflict in South Africa will be given. This will be followed by an overview of the interpersonal conflict management styles developed by Lussier, which will clarify the difference between conflict management and conflict resolution. 


\section{The context of conflict in South Africa}

Lobner (2004) provides an excellent history of conflict in South Africa which gives an indication of the context of conflict in South Africa. The apartheid system, responsible for the deep rifts in South African society, dates back to the time of early white settlements in South Africa in the seventeenth century. Dutch and British settlements gradually spread, driving back San, Khoi and Bantu groups, and leading to the establishment of two Boer republics. The politics of excluding and exploiting the country's black inhabitants assumed new forms in the 1950s and 1960s with the formalisation of the legal and political framework of apartheid. The conflict in South Africa manifested in all facets of daily life governed by the apartheid laws. These laws confined the possession of land by black people to the homelands, forced them to register and to carry passes, condemned private relationships between black and white people, determined different electoral laws and defined different education standards for black and white people, segregated public facilities and reserved jobs for white people. The situation was further entrenched through the banning of nearly all the organisations critical of apartheid.

The main anti-apartheid movement, the African National Congress (ANC), which organised the protest against the apartheid laws, was banned in 1960; most of its leaders were arrested and imprisoned, while others organised their protest from other countries.

Conflict and violence escalated not only among white, colored and black individuals, but also within the white and black sectors of the population. The conflict affected many townships, including those around Johannesburg and Pretoria, which continue to be shaken by violence sparked by political factors, ethnic differences, intimidation, educational crises, mass action and poor socio-economic conditions.

In 1989 the De Klerk government started negotiations with the ANC. As a result, members of the ANC were released from prison and returned from exile, apartheid laws were suspended, and, in April 1994, the ANC won the first non-racial democratic elections. However, violence did not cease with the end of the apartheid system, but continued in the streets, on trains and other forms of transport (e.g. the taxi wars), with a total of 20135 murders reported in 1992 (Lobner, 2004:5). Cilliers (2007:3) in his paper on "Religious and cultural transformation and the challenges for the churches" refers to the identification by the South African Christian Leaders (Sacla) in 2003 of seven "giants". These giants represent the seven greatest 
challenges facing the church, namely HIV and AIDS, crime and corruption, violence, poverty and unemployment, sexism, racism, and the crisis in families. In their newspaper, Sacla refers to the giant named violence.

Looking at the giant violence, there is a murder, suicide or hijacking killing every 26 minutes - 20215 per year. Every 26 seconds a woman or child is raped -1212922 per year. In the rural areas 7755 farms have been attacked and 1287 farmers killed.

The country at present is faced with large numbers of unemployed people with a low standard of education and few marketable skills, and the present leaders are having to contend with the long-term effects of violence and exclusion.

\section{The management of negotiation for consensus as dilemma for conflict resolution}

In the management of conflict in organisations, conflict resolution focuses on negotiation rather than on reconciliation.

According to the rapidly growing body of research literature on organisational conflict, negotiation is the primary process by which organisational members manage conflict. Allred (quoted in Bassi \& Russ-Eft, 1997:35) refers to research by Baron (1989) on the time spent by managers on dealing with conflict. The research focuses on three primary criteria for negotiation in conflict resolution. The first criterion is the extent to which one negotiates an agreement or resolution that serves one's own interests where those interests are in direct conflict with those of the other party. The second criterion relates to the fact that parties may have incompatible interests. The third criterion relates to the fact that conflict in organisations almost always arises among members among whom there are ongoing relationships, and that negotiation preserves and even enhances relationships. In trade-off solutions, compromises are negotiated in which something of lesser importance is given up in order to gain something of greater importance. These examples focus on negotiation as means of conflict resolution in the protection of business interests.

Integrative negotiation involves not only different types of solutions, but also specific behaviours that generate solutions. Empirical research is cited to confirm that integrative negotiations are more effective if parties focus on the communication of their interests 
rather than their positions. Allred (quoted in Bassi \& Russ-Eft, 1997:38) refers to research by Fisher and Dry (1997), who confirm that interests represent the basic needs, values and preferences that parties seek to serve, protect or exercise in negotiation. Lussier (1990:259) discusses five conflict management styles.

\section{- $\quad$ Forcing conflict style}

The forcing conflict style user attempts to resolve the conflict by using aggressive behaviour.

\section{- $\quad$ Avoiding conflict style}

The avoiding conflict style user attempts to passively ignore the conflict rather than resolve it. Avoiders are unassertive and uncooperative, and want to avoid or postpone confrontation.

\section{- Accommodating conflict style}

The accommodating conflict style user attempts to resolve the conflict by actively making space for the other party. The accommodating approach is unassertive and co-operative.

\section{- $\quad$ The compromising conflict style}

The compromising conflict style user attempts to resolve the conflict through assertive give-and-take concessions. This style is adopted because it attempts to meet people's need for harmonious relationships.

\section{- Collaborating conflict style}

The collaborating conflict style user assertively attempts to jointly resolve the conflict by achieving the best solution agreeable to all parties. This style is also called the problem-solving style. The collaborating approach is assertive and co-operative.

Christian leaders are confronted with violent conflict that affects the peace in communities and societies. During the apartheid era in South Africa, conflict was aggravated by four factors: paternalism, where one group was privileged; classification based on ethnicity, with the accompanying curtailment of human rights; institutionalised discrimination; and alienation at subjective interpersonal levels. Christian leaders have a vital role to play in the postapartheid era, and must contend with new conflict factors such as affirmative action, passive racism, discrimination and interpersonal conflict. These conflicts cannot be solved by negotiation alone, because it entails 
not only the interests of involved parties but human rights, discrimination and racism.

\section{Pastoral approaches to conflict resolution}

An approach that addresses the dilemmas of both the use of reconciliation and negotiation skills as instruments for conflict resolution is needed to solve the conflict that emerges from human rights violations, discrimination and racism. Christian leaders are attracted to pastoral approaches for conflict resolution because a pastoral approach entails biblical or spiritual aspects. Redekop (2001:10) says that psychotherapists and pastoral counsellors share a calling to be agents of reconciliation. They seek to bring healing to people and relationships that were wounded through deep-rooted conflict. Various dominant pastoral approaches are identified below.

\subsection{The constructive conflict resolution approach in a context of political violence}

Louw (1987) is well known for his work in the field of Pastoral Theology and the development of what he intended to be a constructive approach to political violence in South Africa. He describes conflict in terms of aggression and existential frustrations: existential frustrations are the basis of existential experiences, and aggression is the totality of reactive behaviour. He describes anger as a reaction to existential frustrations, quoting the following statement by Roher: "We can be frustrated, but the emotion we usually feel when frustrated is anger or hostility." (Louw, 1987:29.) Louw distinguishes between a destructive approach to conflict management, which is limited to violent confrontation, manipulation and avoidance, and a constructive approach, which entails negotiation, consensus, compromise and reconciliation. The latter approach is founded on trust (and the absence of vengeance), the clarification of motives, equal status for relevant role players and a functional forum for negotiations. The essence of this approach is reconciliation and forgiveness. His model is theologically and ethically sound, and theoretically focused on radical renewal and transformation. Louw (1983:50) cites the words of Guinness: "Deep and long-lasting change is not brought about by revolution but by reconciliation and reconstruction." The constructive approach proposed by Louw is theologically sound but not concrete and not viable in terms of behavioural change. Louw gives an example of a destructive approach, where reconciliation did not lead to peace because of the inequality between participants: The Kairos Document published in 1985. In the document it is stated 
that "if the conflict is between two irreconcilable causes or interests in which the one is just and the other is unjust" (Kairos Document, 1985:73) it is not possible to reconcile righteousness and unrighteousness. The polarity between the forces of evil (in the form of a government of oppression) and the God of the oppressed does not allow for reconciliation. The document states clearly that "[t]o speak of reconciling these two is not only a mistaken application of the Christian idea of reconciliation, it is a total betrayal of all that the Christian faith has ever meant" (Kairos Document, 1985:69). Louw came to the conclusion that a model of reconciliation, like the one proposed in the Kairos Document, based on the presupposition that one of the participants needs to be converted, leads to further conflict. But Louw did not provide any concrete examples of his alternative, which he named the constructive approach.

\subsection{The deep-rooted conflict theory of Redekop}

Redekop (2001:11) discusses four different but interrelated theoretical dimensions of deep-rooted conflict. A "deeper look" at the hidden dynamics of conflict is necessary to guide leaders in conflict resolution. Deep-rooted conflict is a threat to human identity needs. Redekop hypothesises that deep-rooted conflict is an indwelling of mimetic structures of violence. Within a relational system such as a family or community, mimetic desire is a sense that our desires are modeled or mediated after the desires of others. Mimetic desires (Girard, 1976) can lead to deep-rooted conflict. We may be extremely frustrated if our mimetic model/object stands in the way of our getting what we have defined as essential to our identity. Conceptually, deep-rooted conflict is seen as increasingly indwelling mimetic structures of violence. The approach to mimetic structures of violence and of blessing shows that identity-based conflict involves forces greater than the individuals who are directly affected. Reconciliation, in contrast to indwelling mimetic structures of violence, is seen as a freedom from mimetic structures of violence and the liberty to explore and internalise mimetic structures of blessing. This blessing can be achieved through helping others to see that they are part of something much bigger, and that they are not alone in what they experience.

Redekop refers to Ricoeur's (1992:10) dialectic of the human person, which differentiates between an idem dimension and an ipse dimension to explain the impact of deep-rooted conflict on the mental structure of a person. The idem is an atemporal construct and has to do with well developed identity characteristics, while the 
ipse dimension is temporal and is always changing. Ipse is oriented towards both the past and the future. Needs associated with idem categories include meaning, action, connectedness, security, recognition and being present. The ipse or self as Ricoeur (1992) names it, is constantly changing in time, looking back into the past memories which feed the idem aspect of meaning, action, story and coherence. Redekop sees reconciliation as a freedom from mimetic structures of violence and a freedom to explore and indwell mimetic structures of blessing. The value of this approach to conflict resolution is that counselors, in this case Christian leaders, are well placed to become agents of mimetic structures of blessing. Redekop, however, did not provide any examples of his approach.

\subsection{Reconciliation and ubuntu}

Richardson comments on the positive evaluation of the TRC in South Africa by Archbishop Desmond Tutu. He quotes Tutu (Richardson, 2008:66):

We South Africans were the unlikeliest lot and that is precisely why God has chosen us. God intends that others might look at us and take courage. God wants to point to us as a possible beacon of hope, a possible paradigm.

Richardson argues that Tutu was convinced that the unique African moral quality of ubuntu was the ingredient which made the achievements possible. He asks: "What is it that constrained so many to choose to forgive rather than to demand retribution, to be magnanimous and ready to forgive rather than to wreak revenge?" He cites Tutu's definition of ubuntu in full to seek the answer in the philosophy of ubuntu:

Ubuntu is very difficult to render into a Western language. It speaks of the very essence of being human. When we want to give high praise to someone we say, 'Yu u nobuntu'; 'Hey, so and so has ubuntu'. Then you are generous, you are hospitable, you are friendly and caring and compassionate. You share what you have. It is to say my humanity is caught up, is inextricably bound up in yours. We belong in a bundle of life. We say a person is a person through other persons. Harmony, friendliness, community are great goods. Social harmony is for us the summum bonum - the greatest good. (Tutu, 1999:3132.)

In his comments on Tutu's discussion of ubuntu, Richardson refers to statements by Maluleke (1999) and Van Binsbergen (2002), both 
of whom claim that ubuntu was unfoundedly drawn upon for the purposes of reconciliation in the context of the TRC. Maluleke (1999:324) says "the TRC has dealt superficially with the deep and glaring wound of South African people and therefore has not effected healing". Van Binsbergen (2002:200) says:

In years to come South African society will yet have to pay the price for the massive and manipulative repression of resentment and anger caused by the historically ungrounded use of ubuntu in the context of the TRC.

Richardson concludes that the use of both reconciliation, with its roots in Christian faith, and ubuntu, with its roots in African tradition, offer little clarity and have little usefulness as universal, abstract concepts, and that reference to them by Tutu as the foundational principles for reconciliation in the TRC was not justified. Such diverse usage may as well result in their co-option by those with ulterior motives.

\subsection{The social construction of conflict}

In her thesis, entitled $A$ pastoral response to some of the challenges of reconciliation in South Africa following on from the Truth and Reconciliation Commission, Brigid Hess (2006) explores the deconstruction of the memories of the Mamelodi Mothers, or Khulumani, a support group of mothers who lost close relatives to political violence during the apartheid era. These women asked that the perpetrators apologise and tell the truth, in exchange for which the women would "offer forgiveness and consolation when we know they are sorry". However, following consultation and meetings with the perpetrators Hess began to focus less on forgiveness, as she came to view forgiveness as a byproduct of action rather than a commodity that can be traded in, quantified or defined. Instead, she came to focus more on the exchange of memories and the superabundant and supernatural ability to show hospitality to the other (Hess, 2006:98). In this pastoral approach to conflict management less emphasis was placed on forgiveness as part of reconciliation, and more on hospitality and exchange of memories.

In the light of the inefficient methods for conflict resolution identified by the above-mentioned examples, including ideological differences (Louw), socialised nurturing patterns (Redekop), cultural philosophies of ubuntu (Tutu) and social constructions (Hess), the following question arises: How do we as Christian leaders approach conflict? An approach which is based on the concrete use of the biblical 
concept of reconciliation and the use of dialogical inquiry, a skill used to solve conflict in marriage counseling, is proposed.

\section{Dialogical inquiry as a path to conflict resolution}

Dialogical inquiry (DI) was developed by Jorge Ferrer (2003), and has links to the use of intentional dialogue by pastoral counselors in marriage counseling. The use of DI for conflict resolution introduces new possibilities for creative and focused solutions.

$\mathrm{DI}$ is regarded as valuable by counselors for three reasons. Firstly, in DI no style of thinking or communication is privileged. Not only is multicultural diversity in communication respected, but the various forms of reflection and communication are valued. Secondly, the goal of DI is not consensus or negotiation, but dialogue. Dialogue questions the two fundamental beliefs of the consensus approach, namely that there is only one world (metaphysical monism), and that there can be only one correct interpretation of one ultimate truth that everybody will accept in negotiations. Thirdly, DI makes provision for new linguistic and new rational dimensions in communication. These include rituals, meditation, storytelling, art and dramatisations.

The word dialogue derives from the Greek dialogos, which can be translated as "speaking through". Dia means through and legein means speak. (dia $=$ through, logos = speaking meaningfully). Dialogue can be contrasted with argumentative discussion, which stems from the Latin discutere (to smash into pieces). In a discussion people often feel that they are in a win-lose situation, and the skills of critical thinking and writing, such as logic, argumentation and rhetoric, are used as weapons to defeat the enemy. In dialogue, by contrast, participants are encouraged to suspend their assumptions and explore them together in non-confrontational ways. In dialogue people learn to detach themselves from their assumptions, and this enables them to receive criticism and, if necessary, change their views. It teaches people to listen deeply to each other and to participate in the collective creation of meaning (Ferrer, 2003:1). These two concepts are compared in Figure 1.

One application of DI is the use of intentional dialogue in the Imago Relationship Therapy (IRT) approach to marriage conflicts and power struggles. IRT, developed by Harville Hendrix in his book Getting the love you want: a guide for couples (1990), draws on elements of Gestalt therapy, client-centeredness, psychoanalysis and behavioural approaches, and uses intentional dialogue as the essential skill for marriage enrichment and conflict management. 
Figure 1: Dialogue and discussion
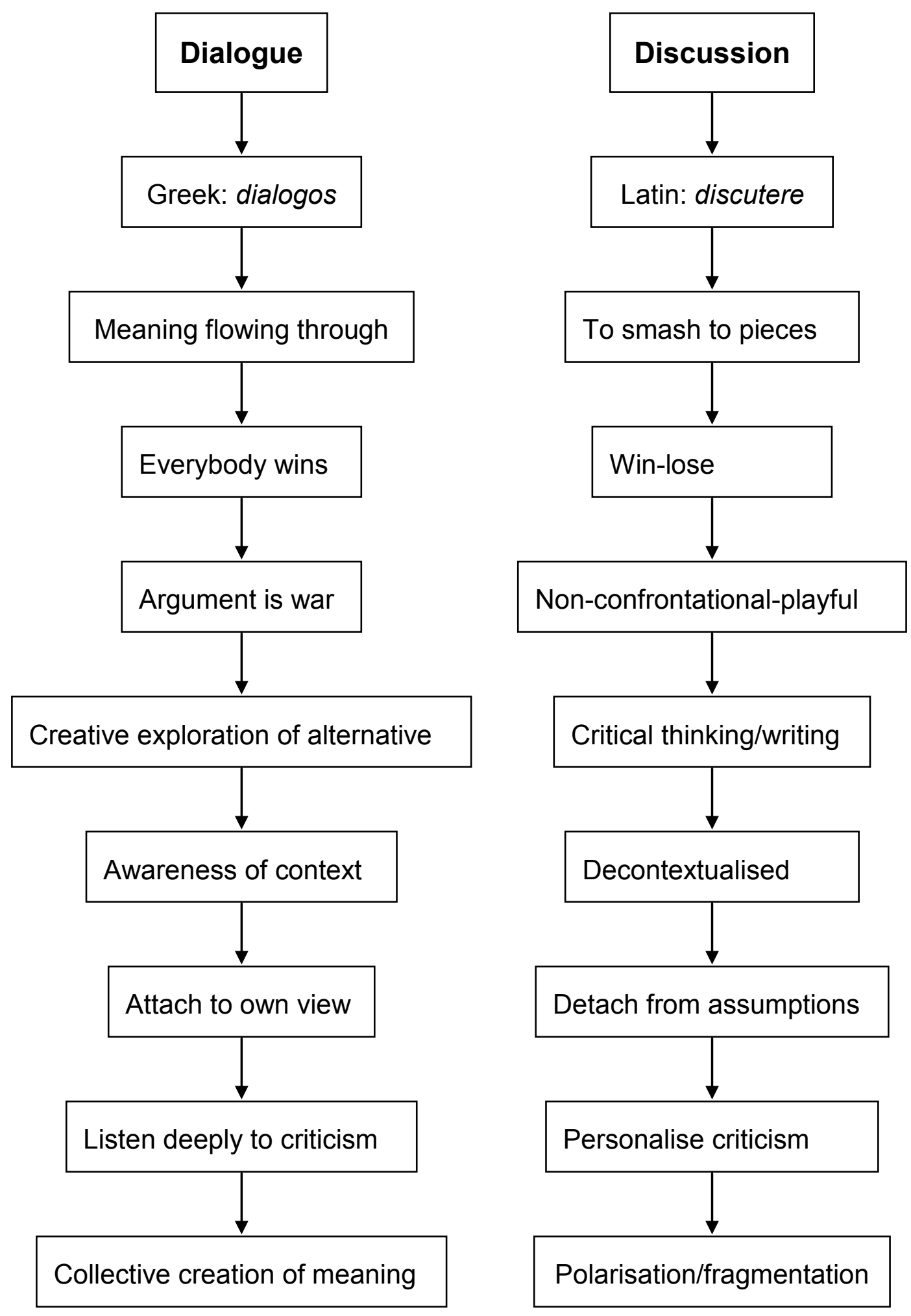

The dialogical relationship as intentional dialogue is based on the biblical concept of covenant. Helen La Kelly Hunt, wife of Harville Hendrix and co-founder of Imago Relationship International, explains a covenant as a dialogical relationship, and identifies five features of the biblical concept of covenant (Hunt quoted in Hendrix \& 
Hunt, 2005:52). These features introduce the possibility of integrating a biblical concept and a social scientific approach. She explains the term covenant with reference to the concepts of relationality, connection, differentiation, forgiveness and paradoxicality. Embedded in these concepts are the essence of reconciliation; thus, the context of reconciliation is the covenant.

Relationality serves as a matrix which brings couples into a divine union far surpassing the modern civil contract. Connection is based on the belief that being open to the awareness of woundedness can lead to healing. Differentiation means that freedom and choice are maintained in order for differences to be a source of strength. Forgiveness refers to the Old Testament concept of hesed, which refers to the attitude and activity which establishes and maintains a relationship. Paradoxicality means that in a covenant there is both a sense of mutual obligation and a sense of grace and forgiveness. Hunt (quoted in Hendrix \& Hunt, 2005:57) provides the following assurance of the universal attainability of dialogue as covenant:

Covenantal relationships are universally attainable. It is a reflection of our innate relationship with the divine, through which we recognize the indissolubility of our relationship to one another as members of the human family. The relationship skills we learn extend to the fullness of life itself.

Intentional dialogue as developed through IRT is based on a threepart process consisting of mirroring, validation and empathising. Mirroring entails repeating exactly to a sending partner what was actually said, not what that person thought that they said or what they wanted to say back as response (Luquet, 1996:25). Validation entails the momentary placement of acceptance into the thoughts and understanding of the other in dialogue. It breaks the symbiotic thought and creates a healthy differentiation through relationship. Empathising is the verbalisation of the feelings, even contradictory feelings, of the partner in dialogue. IRT thus focuses on the reimaging of a life partner by means of dialogue. Luquet (1996:19) explains this process as follows:

This enables partners to view the hurt that underlies each other's behavior and allows them to develop empathy for each other. When a couple really sees the partner's pain they can never view each other in the same way again.

This statement confirms the potential for a new relationship vision and a reimaging of the partner. 
Intentional dialogue for conflict and power struggle resolution is facilitated and practiced by relationship therapists trained and licensed by Imago Relationship International and Imago Africa associations for licensed therapists. The value of this approach for conflict resolution lies in the use of listening skills as part of DI. Listening leads to "entering each other's worlds", to the fulfilment of one another's basic needs and the formulation and activation of behaviour change requests, all of which leads to change. The goal of DI is not the attainment of consensus by means of negotiation. Defenders of "consensus theories" usually fear that disagreement will lead to conflict. It is, however, the ability to cross over to another person's world and entertain the possibilities of a new relationship, which opens new options for conflict management. Although the potential of dialogue for forgiveness is explained by Hunt in her formulation of "covenant as dialogical relationship", the possibility of a balanced focus on both the biblical concept of reconciliation and intentional dialogue merits exploration.

The correlation of $\mathrm{DI}$ with reconciliation opens the possibility of an instrument for Christian leaders to engage in conflict resolution. Reconciliation is interpreted by Louw (1983:105) as including the following key biblical aspects: a new relationship (katallage, cf. 1 Cor. 15:22-28), taking over of guilt (hilasterion, cf. Rom. 3:25), to be set free (kofer, cf. Exod. 21:30) and forgiveness (aphiemi, cf. Col. 2:14). It is the aspect of katallage (a new relationship) which introduces the possibility of correlating reconciliation with dialogue. Louw (1983: 105) characterises this essential aspect of reconciliation in marriage counselling as based on a renewed image of God. Based on a new image, a new relationship is created. If a conflict is approached and managed from the basis of a renewed image of the other party or person in conflict and their perspective, it is possible to forgive or to set free. Dialogical inquiry and intentional dialogue is focused on the reimaging of the partner, on the restructuring of frustrations, the resolving of anger and rage and on revisioning. Brown (1999:136) explains the process of DI as follows:

The dialogue is like an open umbrella under which stand five processes which include Re-Imaging, Re-Structuring, ReSolving, Re-Romanticizing and Re-Visioning.

It is possible to create a correlation between these basic concepts of $\mathrm{DI}$ and the basic levels of meaning of reconciliation. Katallage means a new relation. It correlates with the DI concept of reimaging. This biblical concept does not entail consensus or compromise. Hilasterion means to take over the guilt and this correlates with the 
DI concept of revisioning. This means when the partner's guilt is shared a new vision is created. Kofer means to be set free. This concept correlates with the restructuring in DI. If the partner is set free he is capable of restructuring the relationship. Aphiemi means to forgive and this correlates with the concept of resolving in DI.

\section{Conclusion}

Various approaches to conflict resolution, ranging from negotiation for consensus to manipulation in ubuntu, were explored. An approach consisting of a balanced focus on different aspects of the biblical concept of reconciliation and aspects of intentional dialogue, the usefulness of which is recognised in the fields of pastoral and couples counselling, is proposed. This approach to conflict resolution, if adopted by Christian leaders in a wide range of contexts, has the potential to compensate for the present lack of leadership skills and competencies, as it facilitates two important possibilities: the first is a dialogical approach based on respect and responsibility, and the second is the creation of fundamentally new relationships or visions.

\section{List of references}

BARON, R.A. 1989. Personality and organisational conflict: type A behaviour pattern and self-monitoring. Organisational behavior and human decision processes, 44:281-297.

BASSI, S.J. \& RUSS-EFT, D., eds. 1997. What works: training and development practices. Alexandria: American Society for Training Development.

BROWN, R. 1999. Imago Relationship Therapy: an introduction to theory and practice. New York: Wiley.

CILLIERS, J. 2007. Religious and cultural transformation and the challenges for the churches: a South African perspective. Paper read at the Annual Meeting of the Society for Practical Theology at Huguenot College Wellington, Jan. 2007.

DREYER, Y. 2005. Vergewe en vergeet: 'n pastorale perspektief. Verbum et ecclesia, 26(1):16-34.

FERRER, J.N. 2003. Dialogical inquiry as spiritual practice. Tikkun, 18(1):29-32, Jan./Feb.

GIRARD, R. 1976. Deceit, desire, and the novel: self and other in literary structure. Baltimore: Johns Hopkins University Press.

HENDRIX, H. 1990. Getting the love you want: a guide for couples. New York: Harper \& Row.

HENDRIX, H. \& HUNT, H. la K. 2005. Imago Relationship Therapy perspectives on theory. San Francisco: Jossey-Bass.

HESS, S.B. 2006. A pastoral response to some of the challenges of reconciliation in South Africa following on from the Truth and Reconciliation Commission. Pretoria: Unisa. 
KAIROS DOCUMENT. 1985. The Kairos document: challenge to the church - a theological comment on the political crisis in South Africa. Journal of theology for Southern Africa, 53:61-81.

KISTNER, U. 2003. Reconciliation unjustifiable, justice irreconcilable? Story and narrative in testimony before the South African Truth and Reconciliation Commission. Public Lecture. (Unpublished.)

LOBNER, S. 2004. Life skills for the world of work: experiences in South Africa. http://www.c/o org/public/english/employment/skills/training/pub/pub14.htm Date of access: 15 Mar. 2010.

LOUW, D.J. 1983. Versoening in die huwelik. Durban: Butterworth.

LOUW, D.J. 1987. Versoening in geweld: 'n pleidooi om vrede in Suider-Afrika. Kaapstad: NG Kerk Uitgewers. (Stellenbosse teologiese studies, 15.)

LUQUET, W. 1996. Short-term couples therapy: the Imago model in action. New York: Brunner-Routledge.

LUSSIER, R.H. 1990 Human relations in organizations: a skill-building approach. Chicago: Irwin.

MALULEKE, T. 1999. The truth and reconciliation discourse: a black theological evaluation. (In De Gruchy, J., Cochrane, J. \& Martin, S., eds. Facing the truth: South African faith communities and the Truth and Reconciliation Commission. Cape Town: David Philip. p. 101-113.)

NEUGER, C.C. 2001. Counselling women: a narrative pastoral approach. Minneapolis: Fortress.

REDEKOP, V. 2001. Deep-rooted conflict theory and pastoral counselling: dealing with what one sees. Pastoral sciences, 20(1):9-24.

RICHARDSON, N.R. 2008. Reflections on reconciliation and ubuntu. (In Nicolson, R., ed. Persons in community: African ehics in a global culture. Pietermaritzburg: University of Kwazulu-Natal Press.

RICOEUR, P. 1992. Oneself as another. Chicago: University of Chicago Press.

SMIT, D.J. 1982. Sermon outline on 2 Cor. 5:18-21. Kaapstad: NG Kerk Uitgewers. (Woord teen die Lig, 2: Riglyne vir lydensprediking.)

STRANG, H. \& BRAITHWAITE, J. 2001. Restorative justice and civil society. Cambridge: Cambridge University Press.

TUTU, D.M. 1999. No future without forgiveness. New York: Doubleday.

VAN BINSBERGEN, W. 2002. Ubuntu and the globalization of Southern African thought and society. http://www.shikanad.net/general/ubuntu.htm Date of access: 5 Mar. 2010.

\section{Key concepts:}

deep-rooted conflict

dialogical inquiry

intentional dialogue

reconciliation

ubuntu 


\section{Kernbegrippe:}

bedoelde dialoog

dialogiese ondersoek

diepgewortelde konflik

ubuntu

versoening 